\title{
Blackening of the Surfaces of Mesopotamian Clay Tablets Due to Manganese Precipitation
}

\author{
Etsuo Uchida*, Ryota Watanabe \\ Department of Resource and Environmental Engineering, Faculty of Science and Engineering, \\ Waseda University, Tokyo, Japan \\ Email: weuchida@waseda.jp
}

Received 10 August 2014; revised 8 September 2014; accepted 2 October 2014

Academic Editor: Dr. Xiuzhen Li, Emperor Qin Shihuang's Mausoleum Site Museum, China

Copyright (C) 2014 by authors and Scientific Research Publishing Inc.

This work is licensed under the Creative Commons Attribution International License (CC BY). http://creativecommons.org/licenses/by/4.0/

\begin{abstract}
Blackening was observed on the surfaces of Mesopotamian clay tablets from Umma, Dilbat, Larsa, Ur, Babylon, Uruk, Sippar, and Nippur produced between the Third Dynasty of Ur and the Early Achaemenid Dynasty. Portable X-ray fluorescence analysis revealed that manganese was concentrated on the blackened surfaces. Rod-shaped materials with a length of $100-200 \mathbf{~ n m}$ and a width of $30 \mathrm{~nm}$ were observed using a field emission scanning electron microscope. Distinct peaks were not necessarily obtained by micro-X-ray diffractometer analysis, but several samples of the black material showed peaks identifiable as buserite. These results may suggest that blackening on the surfaces of the clay tablets can be ascribed to the activity of manganese-oxidizing microbe. However, the size of the rod-shaped materials is too small compared to common bacteria.
\end{abstract}

\section{Keywords}

Clay Tablet, Mesopotamia, Maganese Concentration, Manganese-Oxidizing Microbe, Buserite

\section{Introduction}

Clay tablets were used as writing media in Mesopotamia, and cuneiform script was written on their surfaces. Clay tablets began to be used around 3300 BC; those made in the Third Dynasty of Ur, 2113-2006 BC, have been excavated most abundantly. The clay tablets record events related to agriculture, the economy, politics, and other matters.

In 2009, 2011, and 2012, the authors conducted non-destructive chemical analysis and magnetic susceptibility measurements on Mesopotamian clay tablets stored in the Yale Babylonian Collection of Yale University to *Corresponding author. 
elucidate differences in the chemical composition between areas and the provenance of soil. Some of the results obtained in the investigation were published in Uchida et al. (2011) and Sterba et al. (2011). In the course of the study, the authors found blackening phenomena on the surfaces of the clay tablets. The blackened parts appear as spots or occupy wide areas. The blackening phenomena have previously been considered to be caused by soot attached on the surface during firing. However, chemical analysis using a portable $\mathrm{X}$-ray fluorescence analyzer (pXRF) revealed that manganese is concentrated in the blackened parts. Blackening caused by manganese concentration on the surfaces of clay tablets has been reported previously (Laurito et al., 2005; Gütschow, 2012). However, the details of the formation mechanism have not yet been elucidated. Thus, in this study we focused on the blackening phenomena on the surfaces of the clay tablets and conducted a detailed study to determine the formation mechanism.

\section{Methods}

Non-destructive chemical analysis using an Innov-X Systems Delta Premium portable X-ray fluorescence analyzer (pXRF) with a Rh anode X-ray tube $(4 \mathrm{~W})$ was carried out on clay tablets showing blackening. The X-ray beam diameter is $9 \mathrm{~mm}$. The test stand for the PXRF was used in the analysis. The measurement was conducted in "soil mode" using three different filters each for 20 sec (Beam 1 at $40 \mathrm{kV}$ for U, Sr, Y, Zr, Th, Mo, Ag, Cd, Sn and Sb; Beam 2 at $40 \mathrm{kV}$ for Fe, Co, Ni, Cu, Zn, W, Hg, As, Se, Pb, Bi and Rb; and Beam 3 at $15 \mathrm{kV}$ for P, S, $\mathrm{Cl}, \mathrm{K}, \mathrm{Ca}, \mathrm{Ti}, \mathrm{V}, \mathrm{Cr}$, and $\mathrm{Mn}$ ). The pXRF was calibrated in advance using 10 standard rock samples of the Geological Survey of Japan (JA-1, JA-2, JB-1b, JB-2, JB-3, JG-1a, JG-2, JGb-1, JR-1, and JR-2) (Imai et al., 1995). Calibration was conducted successfully for 17 elements: K (549), Ca (1389), Ti (65), V (16), Cr (14), Mn (73), Fe (264), Co (2), Ni (17), Cu (7), Zn (6), As (2), Rb (2), Sr (5), Y (1), Zr (2), and Pb (3). The figures in parentheses show standard deviations (ppm) of the chemical analysis in the average values of the clay tablets.

Samples for analyses were taken from blackened parts on the surfaces of clay tablets with no cuneiform script using a utility knife.

The chemical composition of the collected samples were determined using an electron probe X-ray microanalyzer (EPMA), which is composed of a JEOL JSM-6360 scanning electron microscope and an Oxford Instruments INCA ENERGY energy dispersive X-ray spectrometer. The accelerating voltage was $15 \mathrm{kV}$ and the measuring time was fixed at 60 sec. The blackened parts of the clay tablets were analyzed using the EPMA; non-blackened parts were also analyzed as a control. The samples were coated with carbon. The chemical compositional information from the surface to a few $\mu \mathrm{m}$ in depth was obtained by the EPMA analysis in contrast to from the surface to a few $\mathrm{mm}$ in depth by the pXRF analysis.

Micro-X-ray diffraction analysis was conducted on the samples to identify the constituent minerals of the clay tablets and also the black materials. The analysis was conducted using a Rigaku RINT-RAPID micro-X-ray diffractometer (micro-XRD) with an X-ray tube with a Cu target. The tube current and voltage were $30 \mathrm{~mA}$ and 40 $\mathrm{kV}$, and the measuring time was $30 \mathrm{~min}$. A collimator with $100 \mu \mathrm{m} \phi$ was used in the measurement. The oscillating angles had a range of $7^{\circ}-14^{\circ}$ for the $\omega$ axis $\left(1^{\circ} / \mathrm{min}\right)$ and $-180^{\circ}$ to $+180^{\circ}\left(6^{\circ} / \mathrm{min}\right)$ for the $\phi$ axis.

Additionally, observations were conducted using a Hitachi S-4500S field emission scanning electron microscope (FE-SEM) on the samples taken from the black material of the clay tablets. The accelerating voltage was fixed at $15 \mathrm{kV}$. The samples were coated with platinum.

\section{Blackening on the Surfaces of the Clay Tablets}

The clay tablets investigated in this study are from Umma, Dilbat, Larsa, Ur, Babylon, Uruk, Sippar, and Nippur (Figure 1). The production periods of the studied tablets are from the Third Dynasty of Ur to the Early Achaemenid Dynasty (2113 BC to 330 BC). Economic or political events are described on the surfaces of the clay tablets.

The blackened parts caused by manganese precipitation occur as spots (NBC4846 and BCBT547), or as stains (NBC6240 and NBC30) (Figure 2). Occasionally a blackened part occupies a wide area on the surface of a clay tablet (NCBT2276 and YBC14659). Blackening is frequently observed on the surfaces of clay tablets, and more than $10 \%$ of clay tablets show blackening. The blackening phenomenon was seen on the tablets from all provenances investigated in this study. There is no correlation between the blackening phenomenon and the areas. It is considered that the black material was not formed in storage areas such as museums, but when the tablets were buried in soil.

The thickness of the black material on the surfaces of the clay tablets is less than $0.2 \mathrm{~mm}$ (Figure 3). 


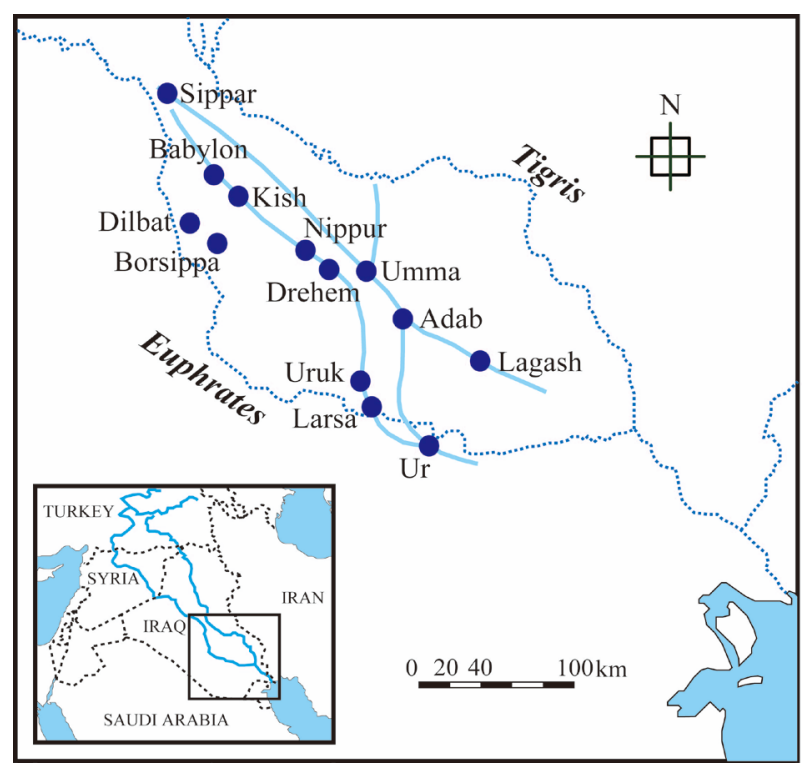

Figure 1. Map showing the provenance of the clay tablets investigated in this study, redrawn after Postgate (1992).

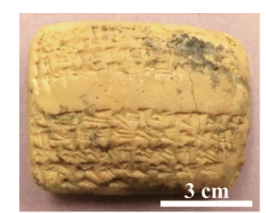

NBC6240

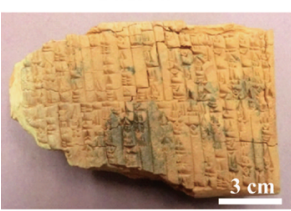

YBC13363

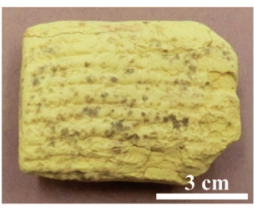

$\mathrm{NBC} 4846$

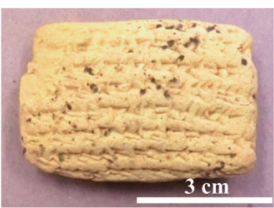

BCBT547

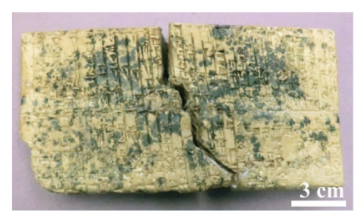

NCBT2276

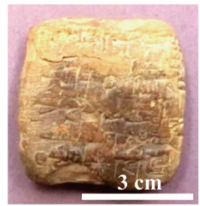

YBC14659

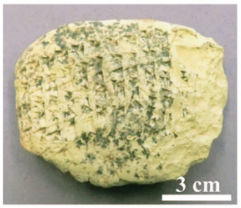

YBC9932

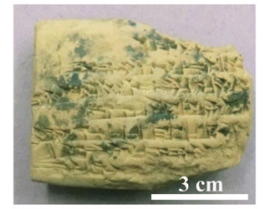

NBC6219

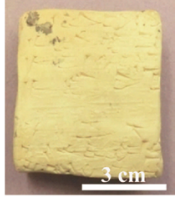

NBC30

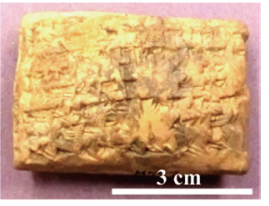

MLC597

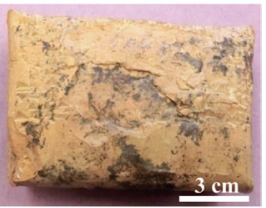

YBC5148

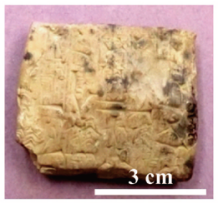

NBC5658

Figure 2. Clay tablets with blackened surfaces investigated in this study.

\section{Results}

\subsection{Chemical Analysis Using pXRF}

The results of the chemical analysis of the black material on the surfaces of the clay tablets using the pXRF are summarized in Table 1. Measurements were conducted on blackened surfaces and non-blackened surfaces of the clay tablets. As the surface is not completely covered by the black material even in the blackened part, and 


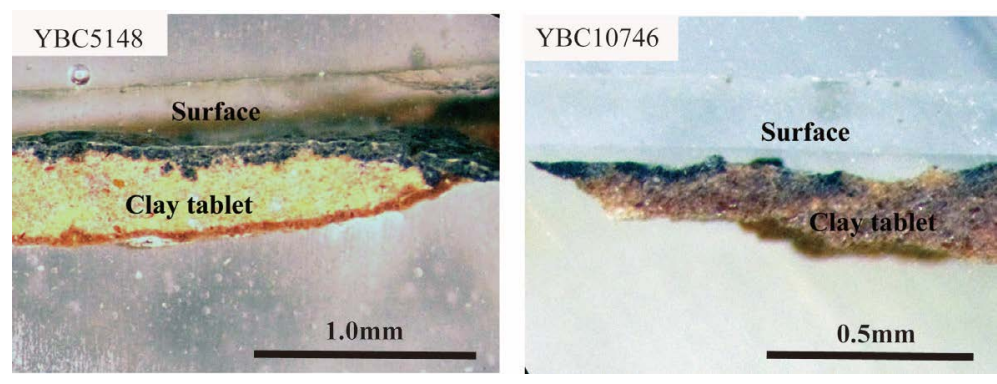

Figure 3. Cross-sections of the black material on the surfaces of clay tablets from Larsa (Old Babylonian period).

Table 1. Results of the chemical analysis of the black material and clay tablets using pXRF.

\begin{tabular}{|c|c|c|c|c|c|c|c|c|c|c|c|c|c|c|c|c|c|c|c|c|}
\hline Area & Period & Sample no. & & $\mathrm{Ca}$ & K & $\mathrm{Ti}$ & $\mathrm{Cr}$ & Mn & $\mathrm{Fe}$ & Co & $\mathrm{Ni}$ & $\mathrm{Zn}$ & As & $\mathrm{b}$ & $\mathrm{b}$ & $\mathrm{Sr}$ & $\mathrm{Zr}$ & $\mathrm{Cu}$ & V & Y \\
\hline \multirow{2}{*}{ 莺 } & \multirow[b]{2}{*}{ Ir III } & \multirow{2}{*}{ YBC14659 } & Clay & 124703 & 37277 & 3121 & 269 & 3212 & 39424 & 27 & 353 & 467 & 20 & 55 & 54.2 & 388 & 124 & 102 & 147 & 22.8 \\
\hline & & & $\begin{array}{c}\text { Black } \\
\text { part }\end{array}$ & 4 & 77 & 3247 & 401 & 7913 & 62 & 25 & 446 & 389 & 16 & 22 & 48.3 & 392 & 113 & 148 & 150 & 22.6 \\
\hline \multirow[b]{2}{*}{$\hat{\vec{\sigma}}$} & & \multirow[b]{2}{*}{ MLC597 } & $\mathrm{C}$ & 10 & 2 & 4126 & 319 & 1510 & 48 & 25 & 359 & 241 & 12 & 25 & 5.6 & 422 & 137 & 5 & 141 & 21.2 \\
\hline & $\begin{array}{c}\text { Neo- } \\
\text { Babylonian }\end{array}$ & & $\begin{array}{c}\text { Black } \\
\text { part }\end{array}$ & 1 & 2 & 4055 & 291 & 4397 & 50 & 31 & 354 & 809 & 21 & 21 & 62.1 & 906 & 136 & 150 & 164 & 25.9 \\
\hline \multirow{2}{*}{ 总 } & \multirow{2}{*}{$\begin{array}{c}\text { Neo- } \\
\text { Babylonian }\end{array}$} & \multirow[b]{2}{*}{ NCBT547 } & Clay & 108 & 2 & 3306 & 190 & 934 & 38865 & 24 & 284 & 199 & 8.1 & 16 & 3 & 309 & 114 & 1189 & 127 & 20.2 \\
\hline & & & $\begin{array}{c}\text { Black } \\
\text { part }\end{array}$ & 130388 & 15467 & 3187 & 167 & 2613 & 38082 & 18 & 438 & 171 & 12 & 10 & 37.1 & 309 & 118 & 113 & 102 & 22.3 \\
\hline & \multirow[b]{2}{*}{ r III } & \multirow[b]{2}{*}{ NBC5658 } & Clay & 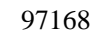 & & 3025 & 214 & 78 & 36 & 18 & 52 & 71 & 13.1 & 12 & 52.9 & 302 & 109 & 19 & 04 & 17.6 \\
\hline & & & $\begin{array}{c}\text { Black } \\
\text { part }\end{array}$ & 113470 & 23915 & 2732 & 174 & 4189 & 36059 & 23 & 462 & 85 & 11 & 24 & 54.6 & 331 & 111 & 48 & 113 & 20.2 \\
\hline \multirow{2}{*}{$\frac{\tilde{0}}{\text { त्र }}$} & \multirow{2}{*}{$\begin{array}{c}\text { Neo- } \\
\text { Babylonian }\end{array}$} & \multirow[b]{2}{*}{ NBC4868 } & Clay & 12 & 1 & 4307 & 261 & 987 & 51 & 28 & 404 & 450 & 14 & 20 & 47.3 & 380 & 152 & 135 & 135 & 26.1 \\
\hline & & & $\begin{array}{c}\text { Black } \\
\text { part }\end{array}$ & 1 & & 4425 & 1226 & 4730 & & 23 & 3022 & 235 & 15 & 21 & 42.1 & 395 & 148 & 9 & 40 & 25.6 \\
\hline \multirow{2}{*}{$\frac{\tilde{0}}{\frac{0}{\pi}}$} & \multirow{2}{*}{$\begin{array}{c}\text { Neo- } \\
\text { Babylonian }\end{array}$} & \multirow[b]{2}{*}{ NBC6219 } & & & & 3701 & 224 & 1619 & & 26 & 11 & 260 & 12 & 4 & 8.3 & 379 & 124 & 450 & 123 & 23.8 \\
\hline & & & $\begin{array}{c}\text { Black } \\
\text { part }\end{array}$ & & 76 & 3967 & 236 & 10203 & 33 & 12 & 616 & 171 & 15 & 25 & 52.6 & 361 & 125 & 104 & 174 & 20.4 \\
\hline \multirow{2}{*}{ 㤩 } & \multirow{2}{*}{$\begin{array}{c}\text { Neo- } \\
\text { Babylonian }\end{array}$} & \multirow[b]{2}{*}{ ЗС9932 } & $\mathrm{Cl}$ & 12 & 1 & 3825 & 131 & 1283 & 46025 & 26 & 392 & 218 & 17 & 10 & 35.5 & 299 & 124 & 68 & 22 & 22.5 \\
\hline & & & $\begin{array}{c}\text { Black } \\
\text { part }\end{array}$ & 1 & 15354 & 3641 & 184 & 9171 & 44830 & 20 & 741 & 389 & 17 & - & 35.5 & 346 & 130 & 90 & 160 & 24.6 \\
\hline \multirow{2}{*}{ 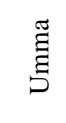 } & \multirow[b]{2}{*}{ Ur III } & \multirow{2}{*}{ NCBT2276 } & Clay & 114890 & 18394 & 2306 & 156 & 797 & 26948 & 20.6 & 228 & 58 & 10.6 & 16 & 51.9 & 246 & 94 & 36 & 77 & 15.8 \\
\hline & & & $\begin{array}{c}\text { Black } \\
\text { part }\end{array}$ & 86184 & 79 & 2790 & 160 & 13588 & 32 & 21 & 868 & 80 & 14 & 27 & 1.1 & 270 & 93 & 5 & 54 & 19.2 \\
\hline \multirow{2}{*}{ 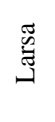 } & \multirow{2}{*}{$\begin{array}{c}\text { Old- } \\
\text { Babylonian }\end{array}$} & \multirow[b]{2}{*}{ YBC5148 } & Clay & 84619 & 36260 & 3463 & 245 & 1140 & & 24 & 260 & 90 & 9.7 & 18 & 55.9 & 361 & 109 & 76 & 116 & 18.2 \\
\hline & & & $\begin{array}{c}\text { Black } \\
\text { part }\end{array}$ & & 21457 & 3058 & 203 & 21996 & 35638 & 10 & 501 & 114 & 21 & 47 & 50 & 322 & 108 & 113 & 263 & 20.5 \\
\hline & & & $\mathrm{Cla}$ & 799 & 65720 & 4916 & 1863 & 993 & 55408 & 25 & 784 & 156 & 2 & 73 & 0 & 231 & 129 & 92 & 195 & 24 \\
\hline 吉 & Ur III & YBC & $\begin{array}{c}\text { Black } \\
\text { part }\end{array}$ & 36 & 08 & 4409 & 1317 & 20275 & 51 & 18 & 844 & 142 & 23 & 40 & 81 & 265 & 127 & 8 & 59 & 23.5 \\
\hline & & & Clay & 110706 & 27767 & 3878 & 233 & 4060 & 43 & 19 & 370 & 456 & 1 & 43 & 50.7 & 374 & 122 & 266 & 121 & 22.4 \\
\hline$\hat{\approx}$ & $\begin{array}{l}\text { ae- } \\
\text { hid }\end{array}$ & NB & $\begin{array}{c}\text { Black } \\
\text { part }\end{array}$ & & 93 & 4233 & 257 & 11806 & 43 & 11 & 507 & 290 & 9 & 33 & 50 & 356 & 124 & 189 & 128 & 21.1 \\
\hline & & & Clay & 125944 & 36130 & 3837 & 462 & 1685 & 43057 & 18 & 367 & 409 & 13 & 20 & 51.1 & 559 & 131 & 103 & 191 & 23.6 \\
\hline $\overrightarrow{\bar{z}}$ & & & $\begin{array}{c}\text { Black } \\
\text { part }\end{array}$ & 100134 & 51106 & 4172 & 469 & 14551 & 45858 & 27 & 946 & 438 & 10 & 22 & 62.3 & 580 & 140 & 128 & 133 & 22.1 \\
\hline
\end{tabular}


also the black material is thin (less than $0.2 \mathrm{~mm}$ in thickness) (Figure 3), it is certain that there is some contribution from the clay itself to the analytical results.

Figure 4 shows the ratio of the chemical composition of the blackened part to that of non-blackened part of the clay tablets. The results show that manganese is concentrated in the blackened parts $2-20$ times more than in the non-blackened parts. Next to manganese, nickel is concentrated in the blackened parts (1 - 7 times). Although not present in every tablet, vanadium, chromium, zinc, arsenic, and lead are concentrated in the blackened parts.

\subsection{Chemical Analysis Using EPMA}

EPMA analysis was conducted on four clay tablets: NBC6219, NBC30, BCBT2276, and YBC5148. We analyzed black material on the surfaces of the clay tablets and also the clay itself for comparison. The analysis was carried out at three points on the black material and at three points on the clay for each sample. The results are summarized in Table 2, and the points analyzed are shown in Figure 5. In the calculation, Mn was treated as $\mathrm{Mn}^{4+}$ and $\mathrm{Fe}$ as $\mathrm{Fe}^{3+}$.

The EPMA analysis reflects the chemical composition in shallower parts of the tablets than the pXRF analysis does. Therefore, the EPMA analysis gives us more accurate information on the chemical composition of the black material. However, EPMA is not suitable for analysis of minor elements because of its low sensitivity.

The results show that that manganese is concentrated in the black material 20 - 240 times more than in the original clay tablets. For Fe, the content is low in the black material compared with the original clay tablet. Therefore, it is considered that the black material is composed essentially of manganese. Although $\mathrm{Si}, \mathrm{Al}, \mathrm{Mg}$, and $\mathrm{K}$ were also detected in the black material, these elements are considered to be derived from the minerals making up the clay tablets. A few percent of S was detected in the black material, but the S content in the clay tablets (non-black material) is usually less than $1 \%$. This fact suggests that $S$ is concentrated more or less in the black material. The Ca content is also high in the black material, and so it is considered that gypsum $\left(\mathrm{CaSO}_{4} \cdot 2 \mathrm{H}_{2} \mathrm{O}\right)$ exists in the black material. In clay tablets NBC6219, NBC30, and YBC5148, a considerable amount of Ca compared with $\mathrm{S}$ is contained in the black material. This may suggest that $\mathrm{Ca}$ is present in calcite as well as in gypsum.

\subsection{Micro-XRD Analysis}

Table 3 summarizes the constituent minerals of the clay tablets, identified using micro-XRD. Quartz and calcite are identified from all clay tablets. Dolomite is found in several clay tablets, as is gypsum. However, it is consi-

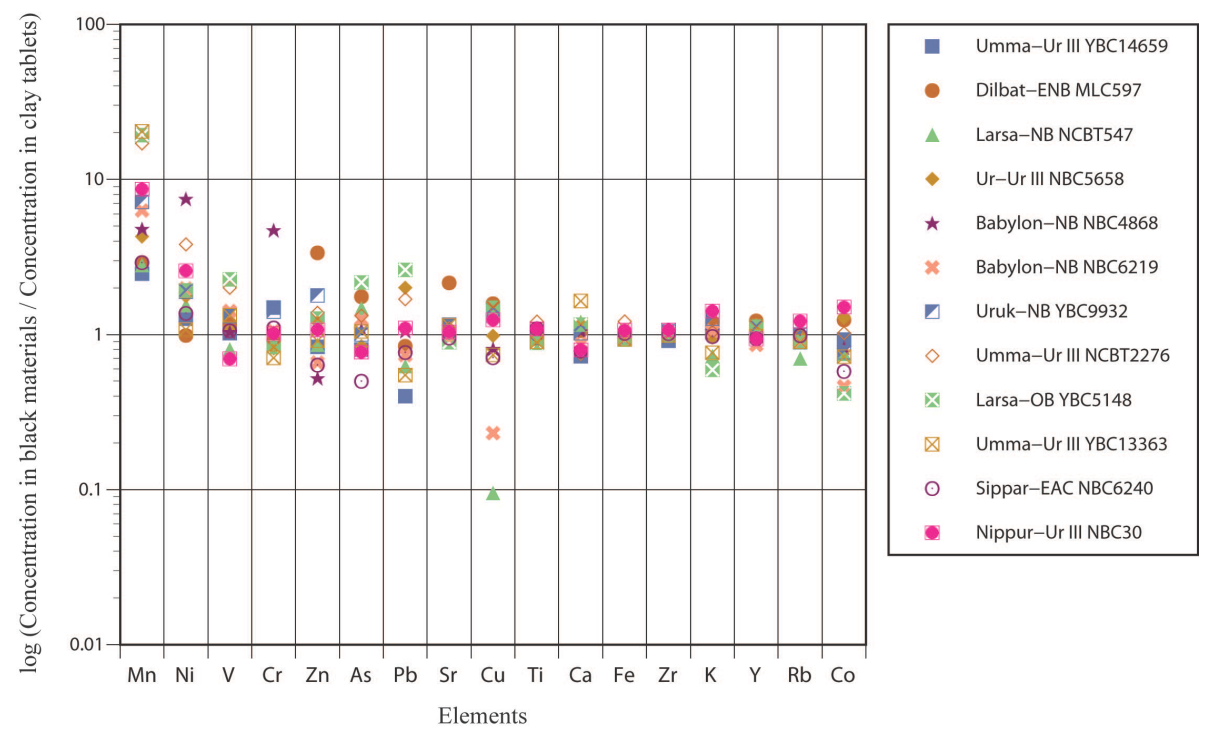

Figure 4. Concentration of each element in the black material on the surface of the clay tablets compared with that in the clay tablets, analyzed by the EPMA. 
Table 2. Results of the chemical analysis of the black material and clay tablets using the EPMA. The totals were normalized to $100 \%$.

\begin{tabular}{|c|c|c|c|c|c|c|c|c|c|c|c|c|}
\hline & \multicolumn{6}{|c|}{ NBC6219 } & \multicolumn{6}{|c|}{ NBC30 } \\
\hline & Black-1 & Black-2 & Black-3 & Clay-1 & Clay-2 & Clay-3 & Black-1 & Black-2 & Black-3 & Clay-1 & Clay-2 & Clay-3 \\
\hline $\mathrm{Na}$ & 0.58 & 0.47 & 0.62 & 0.88 & 1.13 & 1.09 & 0.58 & 0.41 & 0.28 & 1.67 & 0.96 & 1.37 \\
\hline $\mathrm{Mg}$ & 2.89 & 2.82 & 3.05 & 4.89 & 4.93 & 4.50 & 2.85 & 2.94 & 2.35 & 3.63 & 3.39 & 2.89 \\
\hline $\mathrm{Al}$ & 4.43 & 4.49 & 4.84 & 8.72 & 8.17 & 7.82 & 3.09 & 3.44 & 4.98 & 6.93 & 7.02 & 11.15 \\
\hline $\mathrm{Si}$ & 13.70 & 13.74 & 14.33 & 25.10 & 24.61 & 23.41 & 8.69 & 6.80 & 6.51 & 21.33 & 23.99 & 21.96 \\
\hline S & 3.60 & 4.84 & 4.59 & 0.12 & 0.90 & 0.07 & 1.64 & 3.15 & 4.11 & 0.03 & 0.04 & 0.03 \\
\hline $\mathrm{Cl}$ & 0.12 & 0.33 & 0.23 & 0.16 & 0.17 & 0.12 & 2.08 & 3.05 & 4.29 & 0.62 & 0.23 & 0.14 \\
\hline K & 1.61 & 1.64 & 1.52 & 2.67 & 2.13 & 2.35 & 0.60 & 0.23 & 0.46 & 1.95 & 4.10 & 7.03 \\
\hline $\mathrm{Ca}$ & 12.67 & 9.51 & 10.29 & 3.76 & 5.81 & 9.44 & 22.22 & 25.59 & 27.40 & 15.22 & 9.89 & 5.24 \\
\hline $\mathrm{Mn}$ & 13.06 & 13.75 & 10.79 & 0.21 & 0.14 & 0.27 & 17.30 & 13.96 & 7.98 & 0.20 & 0.13 & 0.34 \\
\hline $\mathrm{Fe}$ & 5.09 & 5.15 & 6.52 & 7.87 & 6.21 & 6.62 & 3.30 & 3.09 & 4.41 & 5.84 & 6.43 & 6.13 \\
\hline $\mathrm{O}$ & 42.23 & 43.26 & 43.23 & 45.61 & 45.79 & 44.32 & 37.66 & 37.33 & 37.22 & 42.58 & 43.82 & 43.72 \\
\hline \multirow[t]{3}{*}{ Total } & 100 & 100 & 100 & 100 & 100 & 100 & 100 & 100 & 100 & 100 & 100 & 100 \\
\hline & \multicolumn{6}{|c|}{ ВСВТ2276 } & \multicolumn{6}{|c|}{ YBC5148 } \\
\hline & Black-1 & Black-2 & Black-3 & Clay-1 & Clay-2 & Clay-3 & Black-1 & Black-2 & Black-3 & Clay-1 & Clay-2 & Clay-3 \\
\hline $\mathrm{Na}$ & 0.51 & 0.48 & 0.62 & 1.20 & 0.50 & 0.30 & 3.16 & 0.40 & 1.75 & 1.28 & 0.96 & 1.45 \\
\hline $\mathrm{Mg}$ & 4.75 & 4.97 & 5.40 & 4.36 & 3.96 & 4.59 & 4.68 & 5.10 & 3.08 & 4.59 & 4.66 & 3.65 \\
\hline $\mathrm{Al}$ & 6.88 & 6.38 & 6.88 & 7.62 & 6.96 & 6.34 & 3.45 & 4.70 & 1.87 & 7.72 & 8.74 & 6.32 \\
\hline $\mathrm{Si}$ & 22.29 & 18.36 & 19.15 & 24.28 & 19.87 & 19.65 & 7.38 & 14.32 & 3.92 & 21.35 & 23.72 & 26.95 \\
\hline S & 0.11 & 1.99 & 1.36 & 0.64 & 0.02 & 0.39 & 3.97 & 4.02 & 11.56 & 0.08 & 0.09 & 0.08 \\
\hline $\mathrm{Cl}$ & 1.05 & 3.29 & 2.66 & 0.33 & 0.47 & 0.43 & 4.40 & 1.02 & 1.74 & 0.98 & 0.39 & 1.18 \\
\hline K & 2.25 & 1.59 & 1.81 & 1.94 & 2.44 & 2.10 & 1.07 & 1.33 & 0.59 & 2.19 & 2.64 & 1.83 \\
\hline $\mathrm{Ca}$ & 8.26 & 10.43 & 10.47 & 9.42 & 8.17 & 17.57 & 11.61 & 15.03 & 15.12 & 12.74 & 8.47 & 7.63 \\
\hline $\mathrm{Mn}$ & 4.68 & 5.62 & 4.36 & 0.05 & 0.25 & 0.07 & 19.59 & 6.75 & 16.89 & 0.08 & 0.10 & 0.19 \\
\hline $\mathrm{Fe}$ & 5.43 & 4.28 & 4.52 & 5.11 & 5.39 & 6.52 & 1.99 & 4.96 & 0.98 & 6.04 & 5.55 & 5.48 \\
\hline $\mathrm{O}$ & 43.79 & 42.61 & 42.77 & 45.06 & 51.95 & 42.03 & 38.71 & 42.35 & 42.49 & 42.95 & 44.69 & 45.24 \\
\hline Total & 100 & 100 & 100 & 100 & 100 & 100 & 100 & 100 & 100 & 100 & 100 & 100 \\
\hline
\end{tabular}

Table 3. Constituent minerals of the clay tablets identified using a micro X-ray diffractometer.

\begin{tabular}{|c|c|c|c|c|c|c|c|c|c|}
\hline Area & Period & Sample no. & Quartz & Calcite & Pyroxene & Gypsum & Dolomite & Plagioclase & Buserite \\
\hline Umma & Ur III & YBC14659 & ++ & + & & + & & + & \\
\hline Dilbat & Early Neo-Babylonian & MLC597 & ++ & + & & & & + & \\
\hline Larsa & Neo-Babylonian & NCBT547 & ++ & ++ & & & ++ & & \\
\hline Ur & Ur III & NBC5658 & ++ & ++ & + & + & + & + & \\
\hline Babylon & Neo-Babylonian & NBC4846 & ++ & + & & & ++ & + & \\
\hline Babylon & Neo-Babylonian & NBC6219 & ++ & ++ & & + & & + & \\
\hline Uruk & Neo-Babylonian & YBC9932 & ++ & ++ & & + & & + & \\
\hline Umma & Ur III & NCBT2276 & ++ & ++ & & + & + & & + \\
\hline Larsa & Old-Babylonian & YBC5148 & ++ & + & & + & + & & + \\
\hline Umma & Ur III & YBC13363 & ++ & + & & & & & \\
\hline Sippar & Early Achaemenid & NBC6240 & ++ & ++ & & & + & + & \\
\hline Nippur & Ur III & NBC30 & ++ & ++ & & + & & & + \\
\hline
\end{tabular}

Note: ++: a large amount; +: a small amount.

dered that gypsum was formed on the surface of the clay tablets when they were buried in soil. Additionally, small amounts of plagioclase and pyroxene were identified from some clay tablets. 


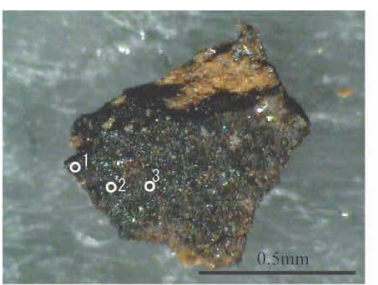

NBC6219(Black part)

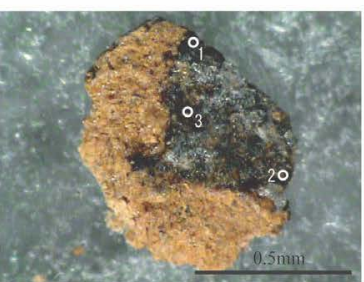

YBC5148(Black part)

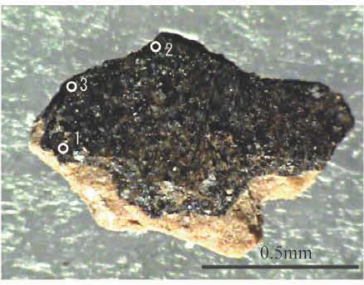

NCBT2276(Black part)

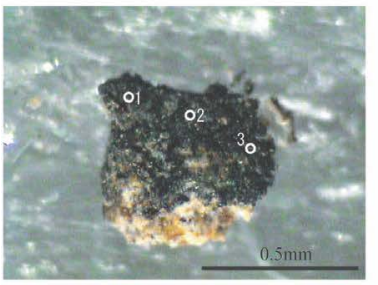

NBC30(Black part)

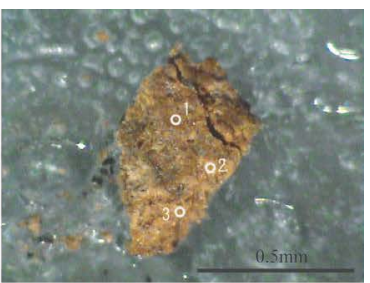

NBC6219(Clay)

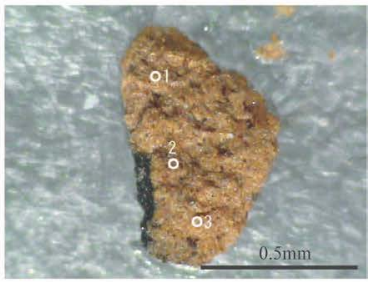

YBC5148(Clay)

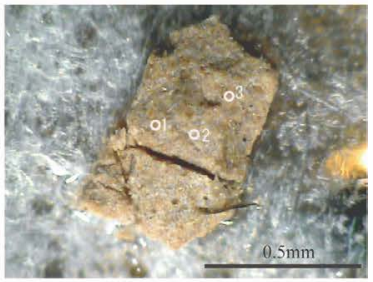

NCBT2276(Clay)

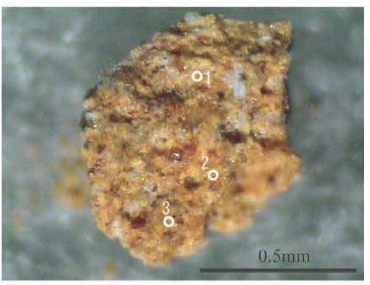

$\mathrm{NBC} 30$ (Clay)

Figure 5. Photographs showing the points analyzed by the EPMA.

In the micro-XRD analysis, a $10 \AA$ manganese mineral was detected in the black material of clay tablets YBC5148, NBC30, and NCBT2276 (Figure 6). Although a large amount of manganese was present in the black material, XRD peaks attributable to manganese minerals were not necessarily obtained from all the clay tablets. This fact may suggest that manganese exists as amorphous materials. Buserite and todorokite are the candidates for $10 \AA$ manganese minerals. To identify them, samples with black material were placed in an oven at $105^{\circ} \mathrm{C}$ for $24 \mathrm{~h}$, and were measured with the micro-XRD. As a result, birnessite newly appeared instead of the $10 \AA$ manganese mineral. This suggests that the $10 \AA$ manganese mineral in the black material is not todorokite, but buserite (Sato et al., 2000). Buserite is known to be a major constituent mineral of manganese nodules on the sea floor (Burns et al., 1983; Giovanoli et al., 1971; Usui \& Someya, 1997). The participation of manganese-oxidizing bacteria in the formation of manganese nodules was pointed out by LaRock and Ehrlich (1975), Thiel (1925), and Wang and Müller (2009). Gypsum $\left(\mathrm{CaSO}_{4} \cdot 2 \mathrm{H}_{2} \mathrm{O}\right)$ was changed into bassanite $\left(\mathrm{CaSO}_{4} \cdot 1 / 2 \mathrm{H}_{2} \mathrm{O}\right)$ by dehydration when the samples were dried at $105^{\circ} \mathrm{C}$.

\subsection{FE-SEM Observations}

Rod-shaped materials with a length of 100 - $200 \mathrm{~nm}$ and a width of $30 \mathrm{~nm}$ were observed on the blackened surfaces of the clay tablets by the FE-SEM. Platy manganese-bearing crystals were also seen. It appears that rodshaped materials were gathered and changed into platy crystals (Figure 7). This may suggest that platy manganese-bearing minerals were formed by recrystallization of the remains of the manganese-oxidizing mi- 

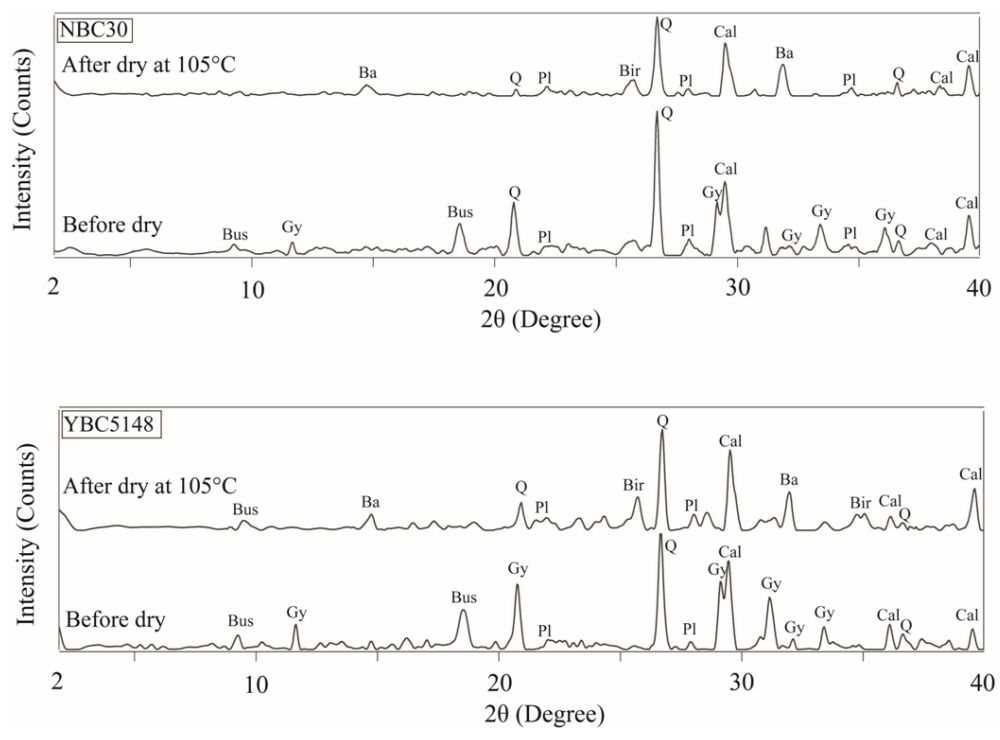

Figure 6. X-ray diffraction patterns of the black material taken from clay tablets NBC30 and YBC5148, obtained using the micro-X-ray diffractometer. Abbreviations: Q, quartz; Pl, plagioclase; Cal, calcite; Gy, gypsum; Ba, bassanite; Bir, birnessite; and Bus, buserite.

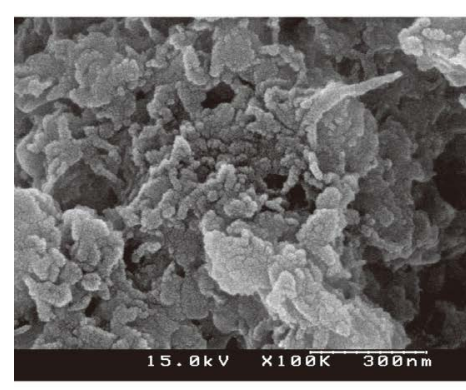

NBC30

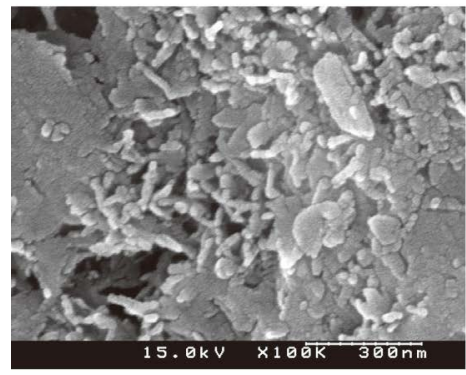

YBC5148

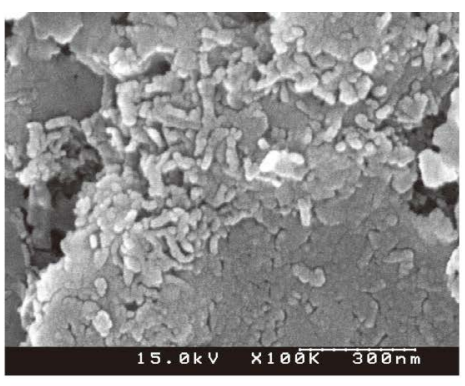

NBC6219

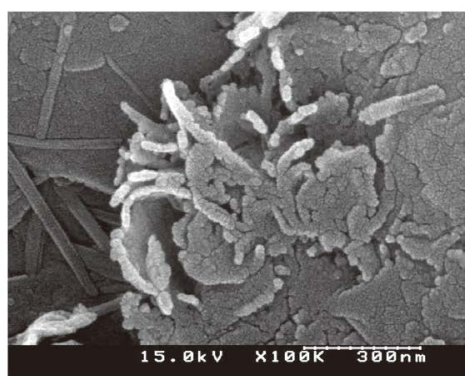

NCBT 2276

Figure 7. FE-SEM images of the black material on the surfaces of the clay tablets.

crobe. However, the size of the rod-shaped materials is too small compared with common bacteria.

\section{Conclusion}

The pXRF and EPMA analyses revealed that the black material on the surfaces of the Mesopotamian clay tablets is mainly composed of manganese. As XRD peaks attributable to manganese minerals were not obtained from all samples by micro-XRD analysis, it seems that the manganese-bearing material is mainly present as amor- 
phous manganese oxide or hydroxide. However, XRD peaks identifiable as buserite were obtained from some samples. Additionally, under the FE-SEM, rod-shaped bacteria (bacilli)-like materials with a length of 100 - 200 $\mathrm{nm}$ and a width of $30 \mathrm{~nm}$ were seen, which were gathered and changed into platy crystals. These facts may suggest that the blackening phenomena on the surfaces of the clay tablets were caused by the action of manganese-oxidizing microbe. Oxidation and concentration of manganese by microbial activity are also seen in manganese nodules and crusts on the sea floor and in desert varnish on the rock surface (Dorn \& Oberlander, 1981; Perry \& Adams, 1978; Potter \& Rossman, 1977; Wang et al., 2011). Similar phenomena of manganese concentration by the microbial activity are observed in caves and the bottoms of rivers (Kanai et al., 2006). Concentration of manganese or iron by microbial activity is frequently seen in the natural world. However, the size of manganese-oxidizing microbe-like materials observed in this study by FE-SEM is one order of magnitude smaller than the manganese-oxidizing microbe found in manganese nodules and desert varnish reported previously (Wang \& Müller, 2009; Dorn \& Oberlander, 1981; Wang et al., 2011). To characterize and identify the microbe-like materials seen in the clay tablets, DNA analysis (16S rDNA) will be indispensable in future studies in spite of difficulty in collecting the sufficient amount of sample.

\section{Acknowledgements}

Clay tablets stored in the Yale Babylonian Collection of Yale University were studied in this investigation. We would like to express our sincere thanks to Prof. B. Foster for permission to access to the Yale Babylonian Collection. During the investigation at Yale University, Dr. U. Kasten and Dr. E. Payne kindly helped us. Dr. C. E. Watanabe of Osaka Gakuin University arranged the investigation at Yale University. We would like to thank them for their useful help. This study was financially supported in part by a Grant-in-Aid for Scientific Research of the Japan Society for the Promotion of Science (Grant no. 23310190: C. E. Watanabe).

\section{References}

Burns, R. G., Burns, V. M., \& Stockman, H. W. (1983). A Review of the Todorokite-Buserite Problem: Implications to the Mineralogy of Marine Manganese Nodules. American Mineralogists, 68, 972-980.

Dorn, R. I., \& Oberlander, T. M. (1981). Microbial Origin of Desert Varnish. Science, 213, 1245-1247. http://dx.doi.org/10.1126/science.213.4513.1245

Giovanoli, R., Feitknecht, W., \& Fischer, F. (1971). Uber Oxidhydroxide des vierwertigen Mangans mit Schichtengitter, 3. Mitteilung: Reduktion von Mangan (Ill)-manganat (IV) mit Zimtalkohol. Helvetica Chimica Acta, 54, 1112-1124. http://dx.doi.org/10.1002/hlca.19710540421

Gütschow, C. (2012). Methoden zur Restaurierung von ungebrannten und gebrannten Keilschrifttafeln—Gestern und Heute. In Berliner Beiträge zum Vorderen Orient Band 22, PeWe-Verlag, Gladbeck.

Imai, N., Terashima, S., Itoh, S., \& Ando, A. (1995). 1994 Compilation Values for GSJ Reference Samples, “Igneous Rock Series”. Geochemical Journal, 29, 91-95. http://dx.doi.org/10.2343/geochemj.29.91

Kanai, Y., Mita, N., Takeuchi, R., Yoshida, S., \& Kuchitsu, N. (2006) Study on Characterization of Manganese-Oxidizing Bacteria in the Natural Environment and Estimation of Its Effect. Bulletin of the Geological Survey of Japan, 57, 1-15. (in Japanese)

LaRock, P. A., \& Ehrlich, H. L. (1975). Observations of Bacterial Microcolonies on the Surface of Ferromanganese Nodules from Blake Plateau by Scanning Electron Microscopy. Microbiology Ecology, 2, 84-96. http://dx.doi.org/10.1007/BF02010383

Laurito, R., Mezzasalma, A., \& Verderrame, L. (2005). Text and Labels: A Case Study from Neo-Sumerian Umma. In R. Biggs, J. Myers, \& M. T. Roth (Eds.), Proceedings of the 51st Rencontre Assyriologique International (pp. 99-110). Chicago: Oriental Institute of the University of Chicago.

Perry, R. S., \& Adams, J. B. (1978). Desert Varnish: Evidence for Cyclic Deposition of Manganese. Nature, 276, 489-491. http://dx.doi.org/10.1038/276489a0

Potter, R. M., \& Rossman, G. R. (1977). Desert Varnish: The Importance of Clay Minerals. Science, 196, 1446-1448. http://dx.doi.org/10.1126/science.196.4297.1446

Sato, Y., Hayashi, J., Nishimori, M., Ono, S., \& Takematsu, N. (2000). Manganese Oxide Minerals Formed by Microbial Mediation. Oceanography in Japan, 9, 193-204. (in Japanese) http://dx.doi.org/10.5928/kaiyou.9.193

Sterba, J. H., Uchida, E., Bichler, M., Sasaki, T., \& Watanabe, C. (2011). NAA and XRF Analyses and Magnetic Susuceptibility Measurement. Scienze dell'antichita, 17, 409-426. 
Thiel, G. A. (1925). Manganese Precipitated by Microorganisms. Economic Geology, 20, 301-310. http://dx.doi.org/10.2113/gsecongeo.20.4.301

Uchida, E., Sasaki, T., \& Watanabe, C. (2011). Non-Destructive Analyses Applied to Mesopotamian Clay Tablets. Scienze dell'antichita, 17, 343-401.

Usui, A., \& Someya, M. (1997). Distribution and Composition of Marine Hydrogenetic and Hydrothermal Manganese Deposits in the Northwest Pacific. In K. Nicholson, J. R. Hein, B. Bühn, \& S. Dasgupta (Eds.), Manganese Mineralization: Geochemistry and Mineralogy of Terrestrial and Marine Deposits (pp.177-198). London: Geological Society of London Special Publication No. 119.

Wang, W., \& Müller, W. E. G. (2009). Marine Biominerals: Perspectives and Challenges for Polymetallic Nodules and Crusts. Trends in Biotechnology, 27, 375-383. http://dx.doi.org/10.1016/j.tibtech.2009.03.004

Wang, X., Zeng, L., Wiens, M., Schloßmacher, U., Jochum, K. P., Schröder, H. C., \& Müller, W. E. G. (2011). Evidence for a Biogenic, Microorganismal Origin of Rock Varnish from the Gangdese Belt of Tibet. Micron, 42, 401-411. http://dx.doi.org/10.1016/j.micron.2010.12.001 
Scientific Research Publishing (SCIRP) is one of the largest Open Access journal publishers. It is currently publishing more than 200 open access, online, peer-reviewed journals covering a wide range of academic disciplines. SCIRP serves the worldwide academic communities and contributes to the progress and application of science with its publication.

Other selected journals from SCIRP are listed as below. Submit your manuscript to us via either submit@scirp.org or Online Submission Portal.
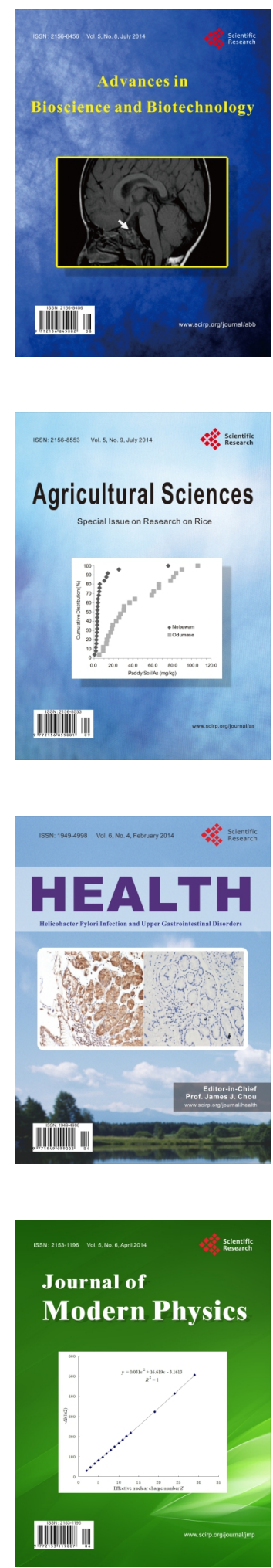
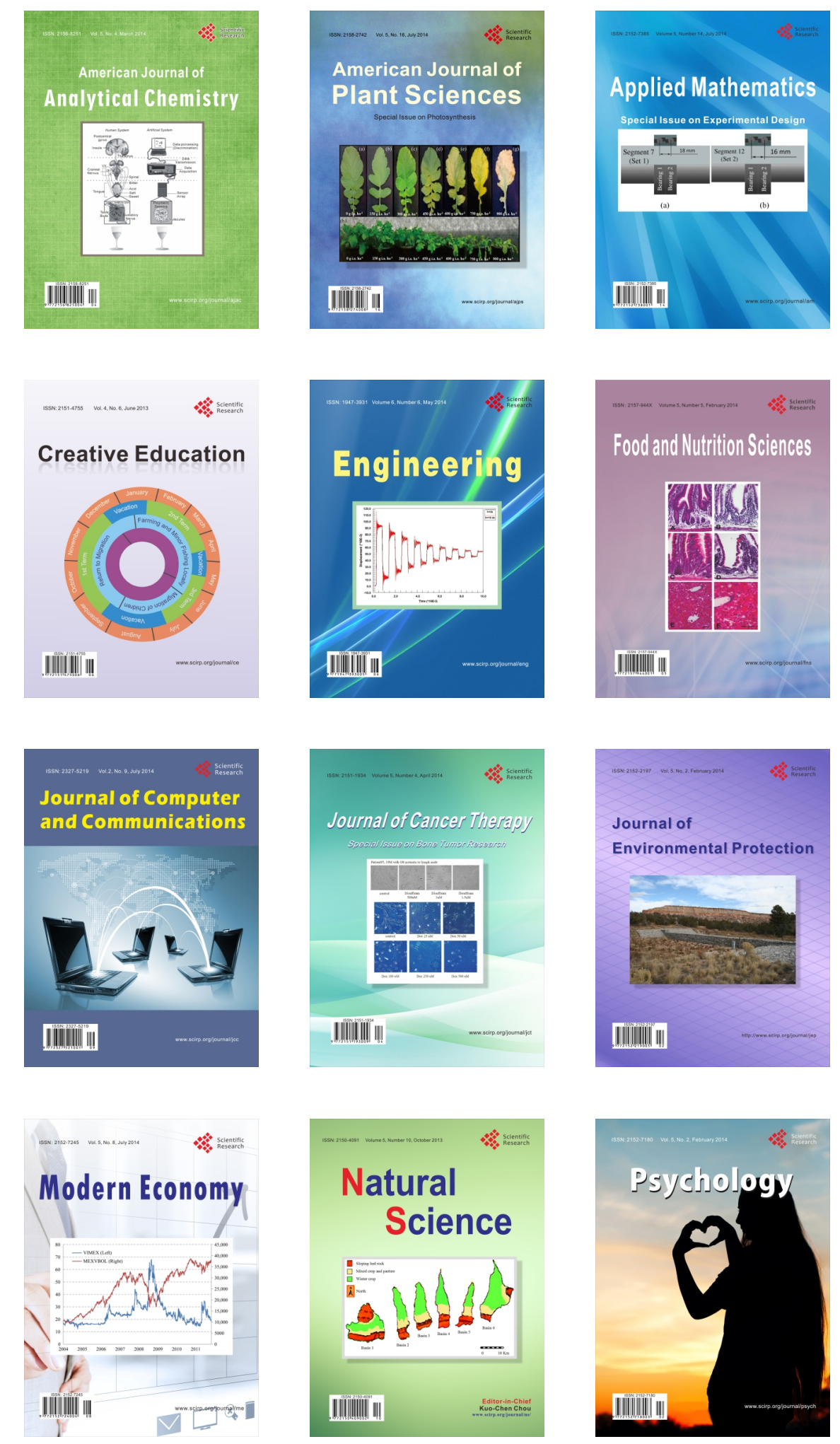